$\left.\begin{array}{c}\text { Sournals } \\ \text { ONTERNATIONAL JOURNAL OF } \\ \text { ORGANIZATIONAL LEADERSHIP }\end{array}\right) \begin{gathered}\text { INDUSTRIAL } \\ \text { MANAGEMENT } \\ \text { INSTITUTE }\end{gathered}$

\title{
The effect of intellectual capital on organizational commitment: A case study of the ministry of economic affairs and finance of Kermanshah province
}

\author{
Shirzad Zeinoddini ${ }^{{ }^{*}}$, Saeid Aibaghi Esfahani ${ }^{2}$, Hossein Soleimani $^{3}$ \\ ${ }^{1}$ Department of Business Management, Malayer Branch, Islamic Azad University, Malayer, Iran \\ ${ }^{2}$ Public Administration Department, Industrial Engineering and Management College, Shahrood Branch, \\ Shahrood, Iran \\ ${ }^{3}$ Department of Mathematics, Malayer Branch, Islamic Azad University, Malayer, Iran
}

\begin{abstract}
Keywords:

Intellectual Capital, Human Capital, Structural Capital, Customer Capital, Organizational

Commitment

Correspondence: shirzadzeinoddini@yahoo. com

This study was an attempt to investigate the effect of intellectual capital on organizational commitment of the staff of the Ministry of Economic Affairs and Finance of Kermanshah province, Iran. The statistical population of the Ministry of Economic Affairs and Finance of Kermanshah was 140 people. Using Morgan Table, a sample of 103 personnel was randomly selected from the population. For gathering data, two researcher-made questionnaires of intellectual capital and organizational commitment were used and the reliability of the questionnaires was tested using Cronbach's alpha. The estimated values of alpha for the questionnaires of intellectual capital and organizational commitment were 0.969 and 0.935 , respectively which clearly demonstrated the reliability of the questionnaires. Structural equation modeling (SEM), multiple regression, and independent t-test were used to assess data. The results of the study demonstrated that there was a significant and positive relationship between intellectual capital and its components and organizational commitment.
\end{abstract}

(C)AIMI Journals

\section{Introduction}

In the $20^{\text {th }}$ century, economy was dependent upon industry. Therefore, at that time, every country or company which possessed more physical properties or financial and tangible assets could create more wealth. However, the $21^{\text {st }}$ century is the time for knowledge-based 
economy. Stewart (1997) considers human capital as the most important property of every organization. Therefore, organizations which have higher levels of intellectual and human capital are expected to have better financial performance. Intellectual capital is far beyond physical and tangible assets. Nowadays, intellectual capital because of knowledge and information producing and wealth creating in knowledge-based economy has an important role in generating gross value added (GVA) and gross domestic product (GDP).

As a result, even at the level of economic agents, the financial performance of companies can be influenced by intellectual and human capital (Zahedi \& Lotfizade, 2011). On the other hand, Bontis (1999) states that traditional thinking in economy which was based on measuring resources and tangible financial assets has been replaced by value creation based on intangible assets in the modern world. In the mid-twentieth century, financial economists tried to attract the companies' attention to a new approach in business. This approach was based on the idea that every organization has unique and distinct capabilities, advantages, and intangible resources which is the main source of value and wealth creation. Therefore, it is necessary to identify and measure all organizational resources and capabilities, and offbalance sheet (OBS) assets. Intellectual capital consists of all the assets which are not mentioned in the company's balance sheet, and it also involves some intangible assets such as the trademark of inventions, competitive advantage of human and structural capital, and environmental relationship which are not mentioned in financial forms through accounting methods. As a result, the growth of intangible assets guarantees competition power and sustainable development (Bontis, 1999).

\section{Statement of the Problem}

Recently many organizations in Iran have declined and a great number of their customers have been lost. Through investigations for finding the reasons for the problems in organizational capital, there have been found some reasons such as weakness of individual perspectives and beliefs, lack of competitive skills to deal with the existing issues, and the problems related to the competence of the personnel for taking job categories and levels correctly. All these reasons are subcategories of human capital which is itself a subcategory of intellectual capital. Another problem encountered by the researchers is the lack of commitment and irresponsibility of some staff. Lack of commitment to the organization has caused problems such as the increase of distrust and the development of challenging environment in the organization and, in consequence, has resulted in prejudice and opposition 
with abnormal social reactions. The increase of aggression and disrespect between colleagues, and also the increase of customers' complaints about the irresponsibility of the staff demonstrate low levels of organizational commitment which, in the case of lack of efficient management and guidance, can cause irresponsibility in the staff, repetition of misbehavior, development of customer abuse, and increase of dissatisfaction in customers. Therefore, the main purpose of this research was to investigate if there was any relationship between the components of intellectual capital and organizational commitment of employees.

\section{Significance of the Study}

Investigating this issue in organizations such as Ministry of Economic Affairs and Finance of Kermanshah is of great importance because organizations not only need to recognize, measure, and manage their intangible assets, they also need to promote and improve their intangible assets (e.g., intellectual capital) consistently. Edvinsson and Malone (1997) believe that organizations which are not able to consistently develop and promote their intellectual capital would exchange their survival to the danger of losing customers and decline.

On the other hand, organizational commitment is a kind of mental and emotional bond which causes the person to consider the organization and its components as a part of him/herself, has identification with the organization, be aligned with the objectives and values of the organization, and consider the organizational objectives as one's own objectives and try to accomplish them. Therefore, this study was significant from another point of view and it was the fact that employees who have higher levels of organizational commitment, in addition to tendency to do their duties completely and efficiently, would have identification with the organization and would be proud of their collaboration (Taghizade Beirami, 2011).

\section{Intellectual Capital}

Because of the importance of the issue, many definitions have been presented for intellectual capital by different researchers. Bontis (1996) states that intellectual capital is a volatile and elusive phenomenon, but as soon as it is discovered and put to use, it can enable the organization to compete with a new source in environment. Dierickx and Cool (1989) believed that intellectual capital is a flow of knowledge in a firm. G. Roos and J. Roos (1997) explain that "Intellectual capital is the sum of the 'hidden' assets of the company not fully captured on the balance sheet, and thus includes both what is in the heads of organizational members, and what is left in the company when they leave" (p. 421). They also express that 
"Intellectual capital is the most important source for sustainable competitive advantages in companies" (p. 421). G. Roos, J. Roos, Edvinsson, and Dragonetti (1997) believed that intellectual capital consists of the sum of the organization members' knowledge and it involves application of this knowledge. Seetharaman, Sooria, and Saravanan (2002) define intellectual capital as the difference between market value of an organization and the cost of replacing its assets. Stewart (1997) believes that intellectual capital is the intellectual material (i.e., knowledge, information, intellectual property, and experience) that has been formalized, captured, and leveraged to create wealth by producing assets which have higher values. Mouritsen, Johansen, Larsen, and Bukh (2001) describe intellectual capital as a widespread organizational knowledge which is specific to every company and allows the company to constantly adapt itself to the changing circumstances. Bontis (1998) argues that "intellectual capital is the pursuit of effective use of knowledge (finished product) as opposed to information (raw material)" (p. 67). Edvinsson and Malone (1997) consider intellectual capital as an applicable knowledge for creating value for a company. Bontis (1997) states that intellectual capital consists of all the processes and properties that are not normally and traditionally mentioned in the company's balance sheet, and it also involves all the intangible assets (e.g., trademarks, brands, and copyright) which are not considered by the modern accounting methods.

\section{Main Components of Intellectual Capital}

Intellectual capital as one of the crucially effective factors in economy consists of three main components, namely human capital, structural capital, and customer capital. Human capital which is the first important component of intellectual capital is a storehouse of organizational knowledge which appears in the staff's behavior (Madhoushi \& Asgharnejad, 2010). According to Roos et al. (1997), the intellectual capital created by colleagues consists of their competence, attitude, and intellectual agility. Competence includes skills and education, and attitude covers the behavioral dimensions of the employee's work (Bontis, Chua Chong, \& Richardson, 2000). Therefore, intelligent employees have the necessary abilities to present efficient procedures for decreasing problems and improving administrative procedures (Bontis et al., 2000). However, although the employees are considered as the most valuable capital of organizations, they cannot be considered as its property forever (Madhoushi \& Asgharnejad, 2010). 
Structural capital is the second component of intellectual capital. Khalique, Shaari, Abdul, and Isa (2011) stated that "structural capital of organizations represents all the non-human storehouses of knowledge" (p. 344). According to Edvinsson and Malone (1997), structural capital consists of the software, hardware, databases, organizational structure, patent, trademarks, and all other organizational capabilities which cause the staff to do their work better and faster. Bontis (1999) defined structural capital as strategies, routines, policies, and all the capabilities which make the organization value something more than its mere physical value. Roos et al. (1997) pointed out that structural capital is what remains in the company when employees are backing home for the night. Bontis (1998) argued that if an organization has poor structural capital, it will be difficult for the organization to reach the full utilization of overall intellectual capital.

Finally, the third component of intellectual capital is called customer capital. Zahedi and Lotfizade (2011) claimed that customer capital consists of the present value and the future potential value of the company's relationships with the customers. Therefore, customer capital is based on the knowledge embedded in the marketing channels and customer relationships that an organization develops through the course of conducting business (Bontis et al., 2000). As a consequence, this capital involves trademarks, market shares, customer information and relationship with customers, branches available to the customers, and commercial deals (Zahedi \& Lotfizade, 2011)

\section{Organizational Commitment}

Bontis (1999) states that organizational commitment is a sort of organizational attachment, bond, and dependence in all people who work and live in a human organization. Therefore, this factor as a dependent variable is influenced by a great number of independent variables. Organizational commitment is also considered as a kind of mental and emotional bond which causes the person to consider the organization and its components as a part of him/herself, have identification with the organization, be aligned with its objectives and values, and consider them as one's own objectives and try to achieve them.

In fact, the above mentioned definition is the outcome of different definitions of organizational commitment and attachment, and is more general than them. It is believed that a person who has a higher level of organizational commitment, in addition to tendency to continue his/her membership in the organization (officially and emotionally), would have identification with the organization and would be proud of his $\backslash$ her collaboration (Edvinsson, 
1997). In addition, such a person may defend the strategies and policies of the organization as much as possible, and regarding the control locus, such a person would take advantage of internal control locus (Edvinsson, 1997). However, commitment depends on the people's attitudes and interests; therefore, it is a relative phenomenon and may be different from one person to another (Edvinsson, 1997).

\section{Conceptual Models}

A number of conceptual models have been presented for intellectual capital and organizational commitment. One of the most popular models for intellectual capital is the one presented by Bontis et al. (2000) which is presented in Figure 1. This model demonstrates three main components of intellectual capital.

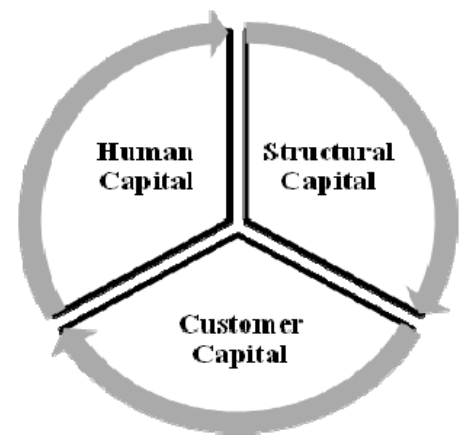

Figure 1. Components of intellectual capital (Adapted from Bontis et al., 2000)

Figure 2 the model for organizational commitment is presented by Taghizade Beirami (2011). This model consists of all the factors which are considered important in organizational commitment. 


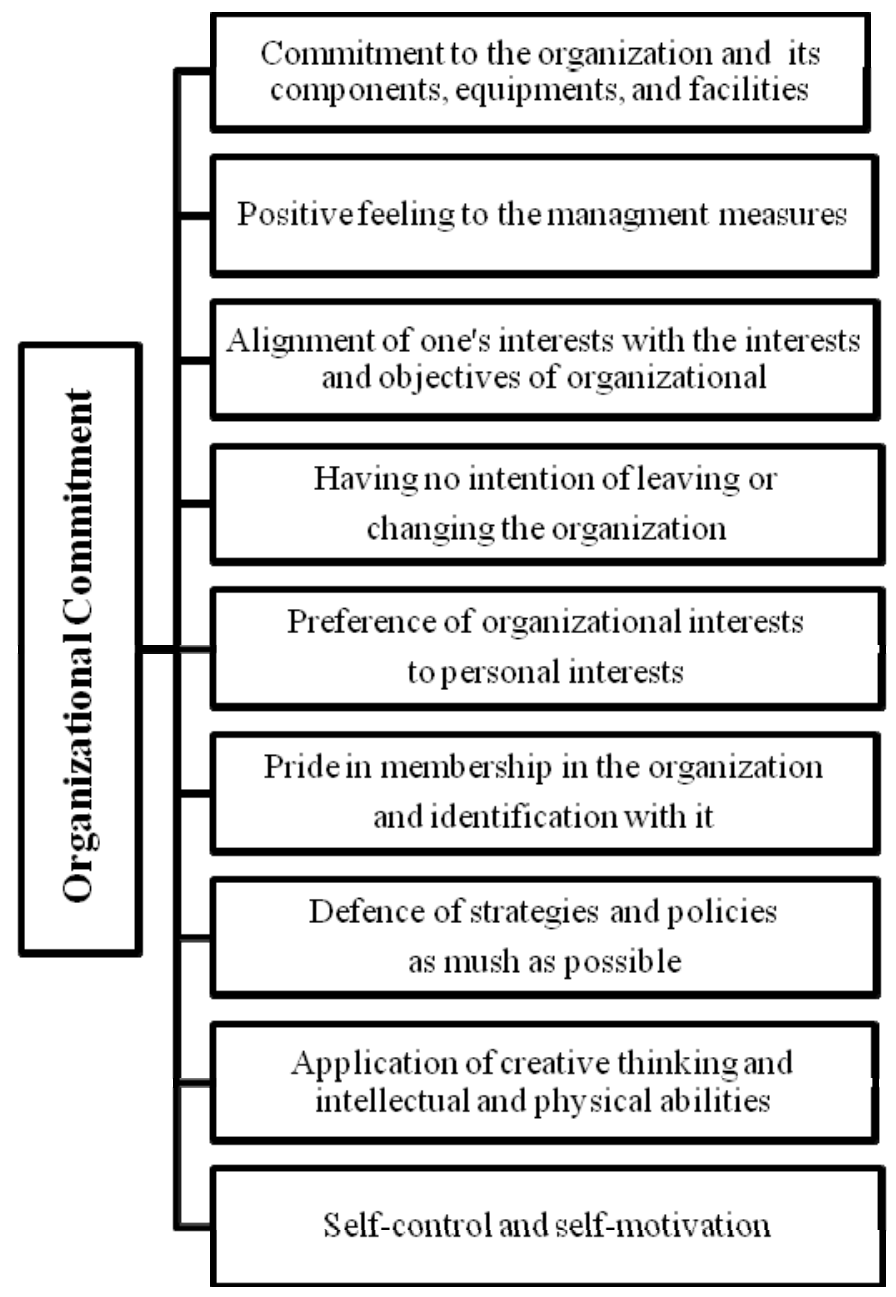

Figure 2. Organizational commitment model (Adapted from Taghizade Beirami, 2011)

\section{The Purpose of Study}

The main purpose of the present study was to investigate the effect of intellectual capital on organizational commitment of the staff of the Ministry of Economic Affairs and Finance of Kermanshah province, Iran. However, the secondary purposes of the study were assessing the amount and patterns of organizational commitment among the staff of this organization, evaluating the status and patterns of intellectual capital among the staff, determining the effect of human capital on organizational commitment of the staff, identifying the amount of the effect of structural capital on organizational commitment of the staff, and establishing the amount of the effect of customer capital on organizational commitment of the staff of the Ministry of Economic Affairs and Finance of Kermanshah province, Iran. 


\section{Research Hypotheses}

This study was an attempt to test some primary and secondary research hypotheses. The primary hypothesis claimed that there was a positive and significant relationship between the intellectual capital and organizational commitment of the staff of the Ministry of Economic Affairs and Finance of Kermanshah province, Iran. On the other hand, this study tried to test three secondary hypotheses. The first secondary hypothesis stated that there was a positive and significant relationship between the human capital and organizational commitment of the staff of the Ministry of Economic Affairs and Finance of Kermanshah province, Iran. The second one claimed that there was a positive and significant relationship between the structural capital and organizational commitment of the staff of the Ministry of Economic Affairs and Finance of Kermanshah province, Iran. Finally, the last one asserted that there was a positive and significant relationship between the customer capital and organizational commitment of the staff of the Ministry of Economic Affairs and Finance of Kermanshah province, Iran.

\section{Method}

The present study was considered as a descriptive correlational research which used SEM for data analysis. Library and field research were used for gathering data. In this study, the current conditions and relationships are described and analyzed, the investigations are done in real organizations by real people, and the variables are not manipulated and they are evaluated in their natural conditions. Therefore, all these factors were the advantages of using this type of research in this organizational study. The reliability of questionnaires was estimated by using Cronbach's alpha.

Statistical population of the study was 140 employees of the Ministry of Economic Affairs and Finance of Kermanshah. Using Morgan Table, a sample of 103 employees was randomly selected from the population. Out of 103 staff, 68.9 per cent of them were male and 31.1 per cent were female. Considering the age range of the personnel, 9.7 per cent of them were 20 to 29 years of age, 43.7 per cent were between 30 to 39 years old, 35 per cent were 40 to 49 years of age, and 11.7 per cent were 50 or more years old. Regarding the educational status of the staff, 4.9 per cent of them were under diploma, 9.7 per cent had diploma, 7.8 per cent had upper-diploma degree, 58.3 per cent were of bachelor's degree, and 19.4 per cent had master's degree. Considering job status of the staff, 82.5 per cent of them were hired on permanent basis and were considered official employees of the organization, 2.9 per cent of 
them were contractual employees, and 14.6 per cent were employed based on compromise agreement. Regarding the field of study, the graduates from accounting, management, economy, and other fields of study comprised 48.5 per cent, 27.2 per cent, 9.7 per cent, and 14.6 per cent of the employees, respectively. In addition, about work experience of the staff, it should be mentioned that 6.8 per cent of the staff had less than 3 years of experience, 7.8 per cent of them had an experience of 3 to 5 years, 31.1 per cent of them had been working for 5 to 10 years, and 54.4 per cent had work experience of more than 10 years. At the present study, two methods of library research and field research were used for gathering data. The library research consisted of studying the books, articles, and journals related to the subject of study and investigating Iranian and foreign scientific websites. The field research involved in creating questionnaires for assessing the variables of the study and distributing them among the staff of the organization under study to collect data.

The instrument for assessing the independent variable of intellectual capital was a researcher-made questionnaire composed of 35 items which involved the questions related to intellectual capital. It should be mentioned that the questionnaire was developed according to 5-point Likert scales including strongly agree, agree, undecided, disagree, and strongly disagree).

\section{Results}

Table 1 presents some information about intellectual capital questionnaire including the number of questions and related questions.

Table 1

Intellectual Capital Questionnaire

\begin{tabular}{lcc}
\hline Intellectual Capital & Related Questions & Number of Questions \\
\hline Human Capital & $1-13$ & 13 \\
Structural Capital & $14-27$ & 14 \\
Customer Capital & $28-35$ & 8 \\
All & $1-35$ & 35 \\
\hline
\end{tabular}

However, the instrument for assessing the dependent variable of organizational commitment of the employees was a researcher-made questionnaire composed of 10 items which were developed according to 5-point Likert scale, namely strongly agree, agree, undecided, disagree, and strongly disagree. Table 2 demonstrates the information about the organizational commitment questionnaire. 
Table 2

Organizational Commitment Questionnaire

\begin{tabular}{lcc}
\hline Organizational Commitment & Related Questions & Number of Questions \\
\hline Commitment to Organizational Set up & $1-4$ & 4 \\
Commitment to Policies & $5-7$ & 3 \\
Commitment to Management Measures & $8-10$ & 3 \\
All & $1-10$ & 10 \\
\hline
\end{tabular}

The questionnaires were tested regarding their validity and reliability. In order to assess the factorial validity of the questionnaires, the opinion of the experts and university professors was asked and the factor loadings of the variables were assessed. Tables 3, 4, and 5 illustrate the standard coefficient (factor loading), variance, and statistical significance of the questions related to each variable of the intellectual capital questionnaire. Analyzing the data demonstrated that the factor loading of all questions had the necessary significance (i.e., $\alpha>1.96)$ to assess the related variables.

Table 3

Factor Loadings for the Variable of Human Capital

\begin{tabular}{ccccc}
\hline Variable & Number of Questions & $\begin{array}{c}\text { Standard Coefficient } \\
\text { (Factor Loading) }\end{array}$ & $\mathrm{S}^{2}$ & Sig. \\
\hline \multirow{5}{*}{ Human Capital } & 1 & 0.68 & 0.46 & 7.70 \\
& 2 & 0.73 & 0.53 & 8.36 \\
& 4 & 0.78 & 0.60 & 9.40 \\
& 5 & 0.79 & 0.62 & 8.81 \\
& 6 & 0.75 & 0.56 & 8.64 \\
& 7 & 0.74 & 0.54 & 7.90 \\
& 8 & 0.76 & 0.57 & 8.72 \\
9 & 0.68 & 0.46 & 8.24 \\
10 & 0.75 & 0.56 & 5.73 \\
11 & 0.72 & 0.51 & 7.53 \\
\hline
\end{tabular}

Table 3 shows the statistics for the variable of human capital in the intellectual capital questionnaire. The calculated variance of the factors demonstrated the relative significance of every factor for assessing the human capital. As it is illustrated in the Table 3, question number 4 with statistical significance of 9.40 was a more significant criterion for assessing human capital, compared to the other questions.

Table 4 illustrates factor loadings for the variables of structural capital. It showed that the significance of question 25 for evaluating structural capital was 9.67. 
Table 4

Factor Loadings for the Variable of Structural Capital

\begin{tabular}{|c|c|c|c|c|}
\hline Variable & Number of Questions & $\begin{array}{l}\text { Standard Coefficient } \\
\text { (Factor Loading) }\end{array}$ & $\mathrm{S}^{2}$ & Sig. \\
\hline \multirow{14}{*}{ Structural Capital } & 14 & 0.75 & 0.56 & 8.75 \\
\hline & 15 & 0.70 & 0.49 & 7.93 \\
\hline & 16 & 0.73 & 0.53 & 8.41 \\
\hline & 17 & 0.76 & 0.57 & 8.90 \\
\hline & 18 & 0.74 & 0.54 & 8.59 \\
\hline & 19 & 0.72 & 0.51 & 8.37 \\
\hline & 20 & 0.66 & 0.43 & 7.36 \\
\hline & 21 & 0.74 & 0.54 & 8.63 \\
\hline & 22 & 0.79 & 0.62 & 9.40 \\
\hline & 23 & 0.70 & 0.49 & 7.93 \\
\hline & 24 & 0.77 & 0.59 & 9.20 \\
\hline & 25 & 0.80 & 0.64 & 9.67 \\
\hline & 26 & 0.78 & 0.60 & 9.38 \\
\hline & 27 & 0.76 & 0.57 & 8.88 \\
\hline
\end{tabular}

Finally, the factor loadings and the statistical significance for the variable of customer capital is presented in Table 5. The results of analysis showed that question 30 with statistical significance of 10.17 was a more significant question for assessing customer capital.

Table 5

Factor Loadings for the Variable of Customer Capital

\begin{tabular}{|c|c|c|c|c|}
\hline Variable & Number of Questions & $\begin{array}{l}\text { Standard Coefficient } \\
\text { (Factor Loading) }\end{array}$ & $S^{2}$ & Sig. \\
\hline \multirow{5}{*}{ Customer Capital } & 28 & 0.77 & 0.59 & 9.05 \\
\hline & 30 & 0.83 & 0.68 & 10.17 \\
\hline & 31 & 0.86 & 0.73 & 10.01 \\
\hline & 32 & 0.84 & 0.70 & 10.04 \\
\hline & 35 & 0.66 & 0.43 & 7.34 \\
\hline
\end{tabular}

After considering data related to the components of intellectual capital, the data about the components of organizational commitment, including commitment to organizational set up, commitment to policies, and commitment to management measures is dealt with. Table 6 shows the data about commitment to organizational set up. It is clearly noticeable from Table 6 that question 1 with statistical significance of 9.77 was a better criterion for assessing commitment to organizational set up.

Table 6

Factor Loadings for the Variable of Commitment to Organizational Set up

\begin{tabular}{ccccc}
\hline Variable & Number of Questions & $\begin{array}{c}\text { Standard Coefficient } \\
\text { (Factor Loading) }\end{array}$ & $\mathrm{S}^{2}$ & Sig. \\
\hline & 1 & 0.82 & 0.67 & 9.77 \\
Commitment to & 2 & 0.78 & 0.60 & 9.11 \\
Organizational & 3 & 0.82 & 0.67 & 9.73 \\
Set up & 4 & 0.80 & 0.64 & 9.40 \\
\hline
\end{tabular}


Next, the data about commitment to policies was analyzed. Table 7 illustrates the data related to this variable. The results demonstrated that question 6 with statistical significance of 12.34 was more significant than the other questions for evaluating commitment to policies.

Table 7

Factor Loadings for the Variable of Commitment to Policies

\begin{tabular}{ccccc}
\hline Variable & Number of Questions & $\begin{array}{c}\text { Standard Coefficient } \\
\text { (Factor Loading) }\end{array}$ & $\mathrm{S}^{2}$ & Sig. \\
\hline Commitment & 5 & 0.85 & 0.72 & 10.44 \\
to Policies & 6 & 0.94 & 0.88 & 12.34 \\
& 7 & 0.81 & 0.65 & 9.81 \\
\hline
\end{tabular}

Finally, Table 8 gives the summary of the statistics and factor loadings of the data from commitment to management measures questionnaire. As it is clear from the table, question 9 with statistical significance of 12.70 could assess the variable better than the other questions.

Table 8

Factor Loadings for the Variable of Commitment to Management Measures

\begin{tabular}{ccccc}
\hline Variable & Number of Questions & $\begin{array}{c}\text { Standard Coefficient } \\
\text { (Factor Loading) }\end{array}$ & $\mathrm{S}^{2}$ & Sig. \\
\hline \multirow{2}{*}{ Commitment to Management } & 8 & 0.86 & 0.73 & 10.56 \\
Measures & 9 & 0.96 & 0.92 & 12.70 \\
& 10 & 0.77 & 0.59 & 9.00 \\
\hline
\end{tabular}

However, apart from determining the validity of the questionnaires, the reliability of the questionnaires was also assessed. In order to achieve this purpose, 30 questionnaires were distributed among the participants and the reliability was tested using Cronbach's alpha $(\alpha)$ reliability coefficient. The calculated values of alpha for the questionnaires of intellectual capital and organizational commitment were 0.96 and 0.93 , respectively. These values of alpha were significant enough to demonstrate the reliability of the questionnaires.

On the other hand, considering the hypotheses of the study, SEM was used for testing the primary research hypothesis, and because of the effect of multiple variables, multiple regression was used for testing the secondary hypotheses of the study. Figure 3 and 4 illustrate the diagrams of SEM and multiple regression for testing the related hypotheses. 


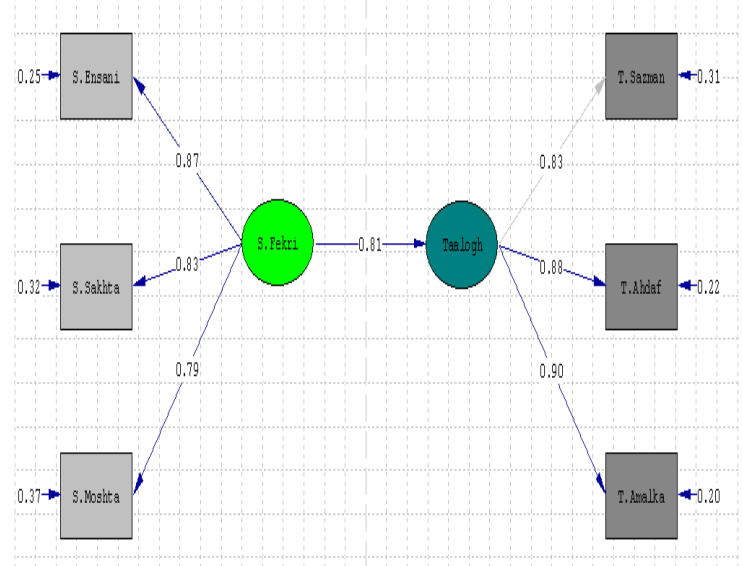

Figure 3. SEM for testing the primary hypothesis (standard coefficient)

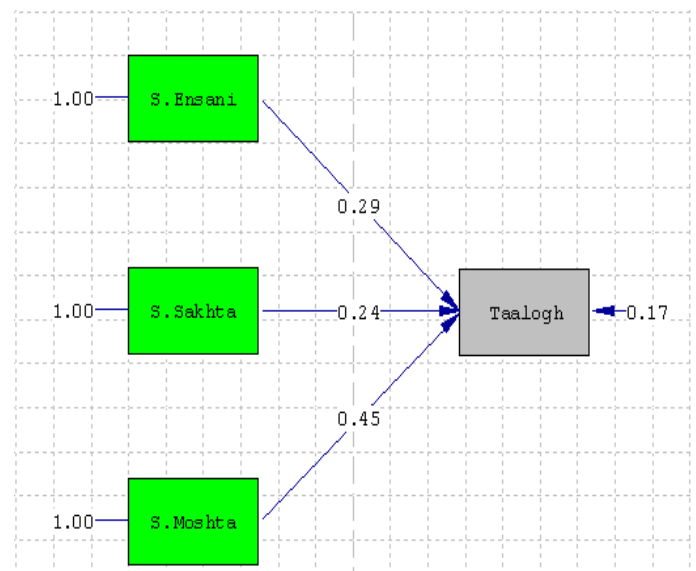

Figure 4. Multiple regression for testing the secondary hypotheses (standard coefficient)

Regarding the significance of the data from models, it should be mentioned that a 0.95 per cent confidence level or a 0.05 per cent significance level $(\alpha)$ was used for testing the hypotheses. Therefore, the $p$-values bigger than +1.96 and smaller than -1.96 were considered as significant in t-test. In other words, if $-1.96<p$-value $>+1.96$, then the score was not significant in t-test. The calculated $p$-values of the t-test for assessing causal relationships between variables are presented in Figures 5 and 6 . 


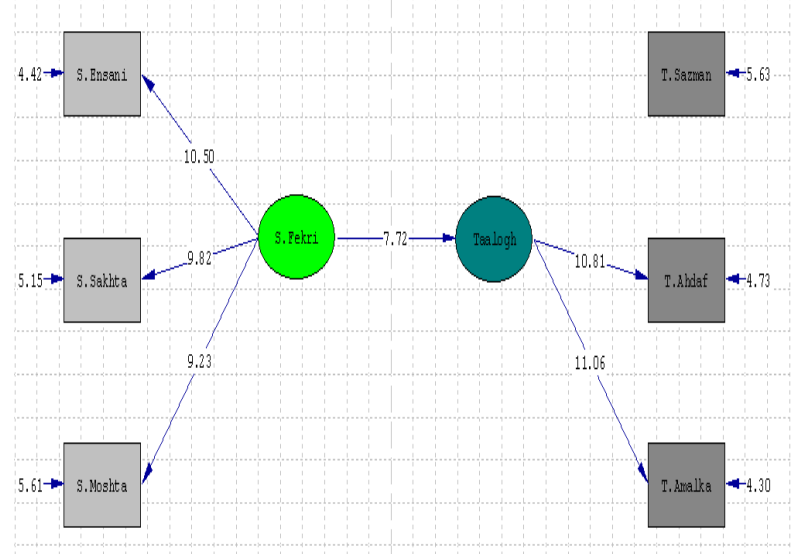

Figure 5. SEM for testing the primary hypothesis ( $p$-value)

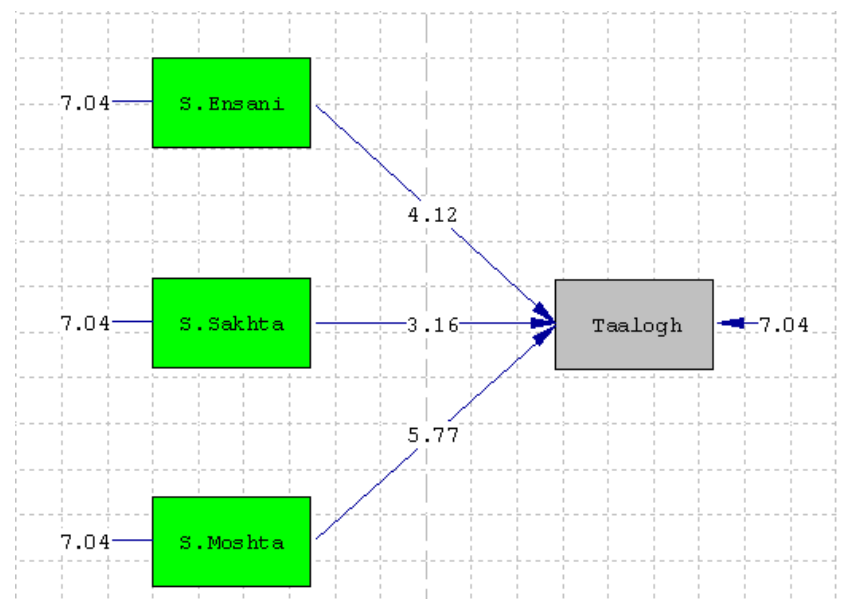

Figure 6. Multiple regression for testing the secondary hypotheses ( $p$-value)

\section{Discussion}

The primary research hypothesis stated that there was a positive and significant relationship between the intellectual capital and organizational commitment of the staff of the Ministry of Economic Affairs and Finance of Kermanshah province, Iran. The data collected for testing this hypothesis showed that the standard coefficient and $p$-value between the two variables were 0.81 and 7.72 (i.e., $p>1.96$ ), respectively. Therefore, the null hypothesis was rejected and it was concluded that intellectual capital had positive and significant effect on organizational commitment of the staff of the Ministry of Economic Affairs and Finance of Kermanshah province. Table 9 gives an illustration of the acceptance or rejection of the research hypotheses using the statistics related to the effect of independent variables on dependent variable. 
Table 9

Standard Coefficient and Statistical Significance between Variables

\begin{tabular}{lccc}
\hline Relationship between Variables & Standard Coefficient & $\begin{array}{c}\text { Sig. } \\
\text { Acceptance } \backslash \text { Rejection of } \\
\text { Hypothesis }\end{array}$ & $\begin{array}{c}\text { Acceptance } \\
\text { Acceptance }\end{array}$ \\
\hline Intellectual Capital -Organizational Commitment & 0.81 & 7.72 & 4.12 \\
Human Capital-Organizational Commitment & 0.29 & 3.16 & Acceptance \\
Structural Capital-Organizational Commitment & 0.24 & 5.77 & Acceptance \\
Customer Capital-Organizational Commitment & 0.45 & & \\
\hline
\end{tabular}

On the other hand, the first secondary hypothesis said that there was a positive and significant relationship between the human capital and organizational commitment of the staff of the Ministry of Economic Affairs and Finance of Kermanshah province, Iran. After gathering and analyzing the data, it was found that the standard coefficient and $p$-value between human capital and organizational commitment were 0.29 and 4.12 (i.e., $p>1.96$ ), respectively. Therefore, the null hypothesis was rejected in favor of the research hypothesis and it was concluded that there was a positive and significant relationship between human capital and organizational commitment of the staff of the Ministry of Economic Affairs and Finance of Kermanshah province.

The second secondary hypothesis stated that there was a positive and significant relationship between the structural capital and organizational commitment of the staff of the Ministry of Economic Affairs and Finance of Kermanshah province, Iran. The data for testing this hypothesis demonstrated that the standard coefficient between the variable of the hypothesis was 0.24 and the $p$-value between them was 3.16 (i.e., $p>1.96$ ). Consequently, the null hypothesis was rejected in favor of the research hypothesis; so, it was proved that there was indeed a positive and significant relationship between the structural capital and organizational commitment of the staff of the Ministry of Economic Affairs and Finance of Kermanshah province.

Finally, the third secondary hypothesis claimed that there was a positive and significant relationship between the customer capital and organizational commitment of the staff of the Ministry of Economic Affairs and Finance of Kermanshah province, Iran. To test this hypothesis, the standard coefficient of 0.45 and the $p$-value of 5.77 (i.e., $p>1.96$ ) were significant enough to reject the null hypothesis and prove the relationship between the customer capital and organizational commitment of the staff of the Ministry of Economic Affairs and Finance of Kermanshah province was positive and significant.

Considering all the results obtained from analyzing the data, it can be claimed that all components of intellectual capital, namely human capital, structural capital, and customer capital, had positive and significant effect on organizational commitment of the staff of the 
Ministry of Economic Affairs and Finance of Kermanshah province. The results are totally consistent with the findings of the other researchers mentioned in the literature review. The positive and significant effect of the components of intellectual capital on organizational commitment of the employees shows the importance of intellectual capital in organizations. The results of the study also proved that the organization under study has had enough effort to improve its human capital (e.g., the staff's knowledge, skills, and competence), structural capital (i.e., internal and external relationships), and customer capital (e.g., operational strategies and procedures, organizational training, and information system). Consequently, it is expected from the organization to be able to improve its organizational commitment through investing in intellectual capital in human, structural, and customer aspects. Precisely speaking, intellectual capital as one of the capabilities and properties of the organization can help the Ministry of Economic Affairs and Finance of Kermanshah province to improve the factors affecting organizational commitment of the employees and it can lead to efficiency and sustainable development of the organization.

\section{Conclusion}

The primary research hypothesis was accepted based on the fact that the results of the Confirmatory Factor Analysis showed a statistical significance between intellectual capital and organizational commitment. In other words, there was a positive and significant relationship between these two variables. According to the finding, the managers and chief executives of the organizations should try to acquire the ability to identify and manage intellectual capitals (e.g., through circulation and efficient use of knowledge) for achieving organizational objectives. In addition, it is better for the managers to lead organizational information system through creating data analysis bases and editing information to present more qualified and precise data to decision-making executives for making more effective decisions and plans. Another recommendation for the managers based on the finding of study can be trying to make a favorable organizational environment because it can have positive effects on organizational commitment. Finally, it is proposed to increase knowledge-based actions in all parts of the organization because it is a useful strategy which on the condition of being followed can cause all parts of the organization to take steps for acquiring and storing knowledge and try to take advantage of the opportunities made inside or outside the organization by chief executives who has always been planning for making opportunities for learning. 
On the other hand, the findings demonstrated statistical significance between human capital and organizational commitment and it demonstrated positive and significant relationship between these two variables. According to this result, it is recommended to identify the strategic jobs of the organization, evaluate the competence level of the staff and use compensatory plans, present training, consultation, and organizational opportunities to improve the future status of the employees who have strong performance, and create favorable environment for the development of staff's ideas and perspectives to enable them to present novel and creative ideas.

In addition, the results indicated that the statistical significance between structural capital and organizational commitment and it demonstrated positive and significant relationship between these two variables. Therefore, based on this finding, it is suggested to use modern and developed structures such as team work and projects in different parts of the organization, make use of data collection systems which facilitate obtaining data, take advantage of the Voice of the Stakeholder (VOS) to get the attitudes of both the employees inside and the customers outside the company.

Finally, the findings showed statistical significance between customer capital and organizational commitment. Therefore, it was proved that there was a positive and significant relationship between these two variables. As a result, based on this finding, it is proposed to make it possible for the customers to send their complaints via portal, deal with the customer complaints and enquiries, employ, train, motivate, and enable the staff to provide service to the customers, give the staff opportunities to collaborate in decision-making, and teach customer service skills to the employees directly dealing with the customers.

\section{Limitations of the Study}

This study suffered from a number of limitations. Although the employees were assured of the confidentiality of the information, some employees avoided answering some personal questions. In addition, no standardized questionnaires were available for assessing the variables. However, the problem was solved through consulting specialists and advisors and making some revisions to the researcher-made questionnaires. All the questionnaires at the end had high levels of validity and reliability. Finally, the last constraint on the study was the limitation of resources and articles related to the organizational commitment. 


\section{Suggestions for Further Research}

While conducting this study, some interesting issues were encountered which could make great contributions in the field. Because of the limitations of time and facilities these issues were not considered at the present study, so they are suggested to be studied in future research. Therefore, this study could be replicated in different provinces or organizations in order to obtain comprehensive required data. The other models of intellectual capital and techniques of data collection (e.g., interview) could be utilized to improve the accuracy and precision of the employees' answers.

\section{References}

Bontis, N. (1996). There's a price on your head: Managing intellectual capital strategically. Business Quarterly, 60(4), 4047.

Bontis, N. (1997). Intellectual capital survey questionnaire. Hamilton, Canada: Institute for Intellectual Capital Research Inc.

Bontis, N. (1998). Intellectual capital: An exploratory study that develops measures and models. Management Decision, 36(2), 63-76.

Bontis, N. (1999). Managing organizational knowledge by diagnosing intellectual capital: Framing and advancing the state of the field. International Journal of Technology Management, 18 (5/6/7/8), 433-463.

Bontis, N., Chua Chong, K. W., \& Richardson, S. (2000). Intellectual capital and business performance in Malaysian industries. Journal of Intellectual Capital, 1(1), 85-100.

Dierickx, I., \& Cool, K. (1989). Asset stock accumulation and sustainability of competitive advantage. Management Science, 35(12), 1504-1511.

Edvinsson, L. (1997). Developing intellectual capital at Skandia. Long Range Planning, 30(3), 320-331.

Edvinsson, L., \& Malone, M. S. (1997). Developing a model for managing intellectual capital. European Management Journal, 14(3), 356-364.

Khalique, M., Shaari, N., Abdul, J. A. N., \& Isa, A. H. B. M. (2011). Intellectual capital and its major components. International Journal of Current Research, 3(6), 343-347.

Madhoushi, M., \& Asgharnejad, M. (2010). Measuring intellectual capital and investigate the association between the intellectual capital and financial returns of companies. The Iranian Accounting and Auditing Review, 16(4), $101-116$.

Mouritsen, J., Johansen, M. R., Larsen, H. T., \& Bukh, P. N. (2001). Reading an intellectual capital statement: Describing and prescribing knowledge management strategies. Journal of Intellectual Capital, 2(4), 359-383.

Roos, G., \& Roos, J. (1997). Measuring your company's intellectual performance. Long Range Planning, 30(3), 413-426.

Roos, G., Roos, J., Edvinsson, L., \& Dragonetti, N. C. (1997). Intellectual capital: Navigating in new business landscape. New York: New York University Press.

Seetharaman, A., Sooria, H. H. B. Z., \& Saravanan, A. S. (2002). Intellectual capital accounting and reporting in the knowledge economy. Journal of Intellectual Capital, 3(2), 128-148.

Stewart, T. (1997). Intellectual capital: The new wealth of organizations. New York: Nicholas Brealey Publishing.

Taghizade Beirami, G. (2011). Effective factors on organizational commitment. Tabriz: Yase Nabi.

Zahedi, S., \& Lotfizade, F. (2011). Aspects and models of calculating intellectual capital. Journal of Management Studies, 55(15), 21-64. 